\title{
PENGARUH RELATION BENEFIT DAN DESTINATION QUALITY TERHADAP SATISFACTION PENGUNJUNG WISATA PULAU PAHAWANG SELAMA PANDEMI COVID 19
}

\author{
Mustika Sari, Dora Rinova \\ Fakultas Ilmu Sosial dan Ilmu Politik \\ E-mail: \\ mustikasr88@gmail.com \\ dora@ubl.ac.id
}

\begin{abstract}
ABSTRAK
Kesimpulan dari spot-spot industri Wisata pantai di Lampung dilakukan untuk memutus mata rantai penyebaran dan penularan (Covid-19) yang saat ini menyebar di Lampung. Penelitian ini bertujuan untuk mengetahui dampak keunggulan koneksi dan kualitas obyektif terhadap pemenuhan kunjungan tamu ke Pulau Pahawang saat pandemi Covid 19. Pemeriksaan ini diingat untuk eksplorasi kuantitatif. Populasi dalam penelitian ini adalah wisatawan pantai di Provinsi Lampung berdasarkan informasi tahun 2019, sebanyak 17.183 ekor dan contoh ukuran 100 ekor. Pemeriksaan dalam pemeriksaan ini menggunakan pemeriksaan kambuh langsung yang berbeda. Hasil penelitian menunjukkan bahwa thitung untuk variabel keunggulan koneksi adalah 3,536 (thitung $=3,536>$ tabel $=2,045$ ) dan sig $=0,000<0,05$ yang berarti terdapat pengaruh keunggulan koneksi terhadap pemenuhan tamu ke Pulau Pahawang industri wisata. Hasil uji-t untuk variabel kualitas obyektif sebesar 4,127 (thitung $=4,127>$ ttabel $=2,045)$ dan sig $=0,026<0,05$ yang berarti terdapat pengaruh kualitas obyektif terhadap pemenuhan tamu terhadap kunjungan ke Pulau Pahawang. Fhitung = $22.650>$ Ftabel $=2.100$, artinya terdapat pengaruh keunggulan koneksi, kualitas obyektif, dan kompensasi terhadap pemenuhan tamu kunjungan ke Pulau Pahawang.
\end{abstract}

KataKunci: Manfaat Relasi, Kualitas Destinasi, Kepuasan dan Tamu

\section{PENDAHULUAN}

Lampung merupakan wilayah paling selatan Pulau Sumatera yang berjajar di sebelah utara Bengkulu dan Sumatera Selatan. Provinsi Lampung dengan ibu kota Bandar Lampung, terminal udara utamanya adalah Bandara Raden Inten II. Awal 2009, Pemerintah Provinsi Lampung memberangkatkan waktu kunjungan wisatawan. Macam-macam industri wisata yang bisa dikunjungi di Lampung

Tabel 1.1

Jenis Wisata yang ada di Provinsi Lampung

\begin{tabular}{|c|l|l|l|}
\hline No & \multicolumn{1}{|c|}{ Tempat Wisata } & \multicolumn{1}{c|}{ Kabupaten } & \multicolumn{1}{c|}{ Jenis Wisata } \\
\hline 1 & Teluk Kiluan & Tanggamus & Wisata pantai \\
\hline 2 & Pulau Pahawang & Pesawaran & Wisata pantai \\
\hline 3 & Tanjung Setia & Pesisir Barat & Wisata pantai \\
\hline 4 & Pulau Pisang & Pesisir Barat & Wisata pantai \\
\hline 5 & Pantai Mandiri & Pesisir Barat & Wisata pantai \\
\hline 6 & Pantai Gigi Hiu & Lampung Selatan & Wisata pantai \\
\hline
\end{tabular}

Sumber: Dinas Pariwisata Provinsi Lampung (2020)

Jenis industri wisata yang umumnya dikunjungi oleh wisatawan asing dan lokal adalah industri wisata bahari atau industri wisata pantai yang tersebar di beberapa wilayah dan masyarakat perkotaan di Provinsi Lampung. 
Tabel 1.2

Jumlah Kunjungan Wisatawan Asing dan Domestik di Provinsi Lampung Tahun 20142019

\begin{tabular}{|c|c|c|c|c|c|c|c|}
\hline \multirow{2}{*}{ No } & \multirow{2}{*}{ Tahun } & \multicolumn{4}{|c|}{ Wisatawan } & \multirow{2}{*}{ Jumlah } & \multirow{2}{*}{$\%$} \\
\hline & & Asing & $\%$ & Lokal & $\%$ & & \\
\hline 1 & 2014 & 58.205 & 8,26 & 2.581 .165 & 7,46 & 2.639 .370 & 7,47 \\
\hline 2 & 2015 & 75.590 & 10,73 & 3.392 .125 & 9,80 & 3.467 .715 & 9,82 \\
\hline 3 & 2016 & 95.528 & 13,56 & 4.327 .188 & 12,50 & 4.422 .716 & 12,52 \\
\hline 4 & 2017 & 114.907 & 16,31 & 5.530 .803 & 15,98 & 5.645 .710 & 15,99 \\
\hline 5 & 2018 & 115.053 & 16,33 & 7.381 .774 & 21,33 & 7.496 .827 & 21,23 \\
\hline 6 & 2019 & 245.372 & 34,82 & 11.395 .827 & 32,93 & 11.641 .199 & 32,97 \\
\hline \multicolumn{2}{|c|}{ Jumlah } & 704.655 & 100,0 & & 100,0 & 35.313 .537 & 100,0 \\
\hline
\end{tabular}

Sumber: BPS Provinsi Lampung diolah (2019)

Berdasarkan Tabel 1.2, dapat dilihat bahwa kuantitas kunjungan wisatawan asing dan terdekat di Provinsi Lampung pada tahun 2014-2019 meningkat dari tahun ke tahun. Jumlah kunjungan terbanyak terjadi pada tahun 2019 yaitu sebanyak 11.641 .199 orang. Besaran kunjungan wisatawan bahari atau pantai di Provinsi Lampung tahun 2019:

Tabel 1.3

Jumlah Kunjungan Wisatawan Bahari / Pesisir di Provinsi Lampung

\begin{tabular}{|c|c|c|}
\hline Bulan & Jumlah Pengunjung (orang) & Persentase $(\%)$ \\
\hline Januari & 16.250 & 9,46 \\
\hline Februari & 15.200 & 8,85 \\
\hline Maret & 14.520 & 8,45 \\
\hline April & 12.270 & 7,14 \\
\hline Mei & 11.780 & 6,86 \\
\hline Juni & 12.450 & 7,25 \\
\hline Juli & 16.210 & 9,43 \\
\hline Agustus & 14.200 & 8,26 \\
\hline September & 12.350 & 7,19 \\
\hline Oktober & 15.470 & 9,00 \\
\hline November & 14.120 & 8,22 \\
\hline Desember & 17.010 & 9,90 \\
\hline Jumlah & 171.830 & 100 \\
\hline Rata-rata & 14.320 & 8,33 \\
\hline
\end{tabular}

Sumber: BPS Provinsi Lampung dihimpun (2019)

Jumlah kunjungan wisatawan bahari / pantai di Provinsi Lampung pada tahun 2019 yang terombang-ambing, dimana kunjungan paling sedikit terjadi pada Mei 2019 yaitu sebanyak 1.178 orang $(6,86 \%)$, sedangkan kunjungan yang paling penting terjadi pada bulan Desember 2019 khususnya. 1.701 orang $(9,90 \%)$. Kemudian diperoleh informasi sehubungan dengan kecenderungan umum para pengunjung industri wisata bahari / pantai di Provinsi Lampung pada tahun 2019 
Tabel 1.4

Data Kepuasan Pengunjung Wisata Bahari / Pesisir Provinsi Lampung Tahun 2020

\begin{tabular}{|c|c|c|c|}
\hline \multirow{2}{*}{ No } & \multirow{2}{*}{ Fasilitas } & \multicolumn{2}{|c|}{ Kepuasan } \\
\hline & & Puas & Tidak Puas \\
\hline 1 & Restoran & 1 & \\
\hline 2 & Kamar mandi & & 0 \\
\hline 3 & Toilet umum & & 0 \\
\hline 4 & Akomodasi & 1 & \\
\hline 5 & Pusat Informasi Wisata & & 0 \\
\hline 6 & Posko Keamanan & 1 & \\
\hline 7 & Penyewaan pondok & & 0 \\
\hline 8 & Warung & 1 & \\
\hline 9 & Mushola & & 0 \\
\hline 10 & Area Playground Anak-anak & & 0 \\
\hline 11 & Posko Gerbang Karcis Masuk/Keluar & & 0 \\
\hline & Jumlah & 4 & 7 \\
\hline & Persentase (\%) & $36,4 \%$ & $63,6 \%$ \\
\hline
\end{tabular}

Sumber: Data diolah (2020)

Kesimpulan dari spot industri wisata bahari di Lampung ini selesai dilakukan untuk memutus mata rantai penyebaran dan penularan (Covid-19) yang sampai saat ini menyebar di Lampung. tidak, saat ini terlihat ada tamu dari berbagai tempat dan daerah. Pengawas destinasi liburan juga melarang tamu berkunjung ke sana. Sementara itu, petugas yang berhenti dan penjaga gerbang juga tidak terlihat karena tidak adanya tamu. Kondisi tersebut terlihat pada Pantai Sari Rutut, Pantai Klara, Pantai Mutun, dan berbagai kunjungan pantai di sepanjang bibir pantai Teluk Lampung. Lokasi wisata pulau juga banyak dikunjungi wisatawan, seperti Pulau Pahawang dan Pulau Tegal Mas. Secara umum, secara konsisten, atau acara sekolah dan kantor, para tamu yang mengapresiasi acara yang ditempati mengunjungi keberatan wisatawan di wilayah Teluk Lampung.

\section{TINJAUAN PUSTAKA}

Iklan sosial menunjukkan bahwa hubungan antara organisasi dan memilih klien dimasukkan ke dalam hubungan jangka panjang yang biasanya membantu. Kotler (2007) menyatakan bahwa relationship promotion dapat dikatakan memiliki makna, keunggulan koneksi adalah sebuah siklus dalam menarik, menjaga dan meningkatkan asosiasi dengan individu-individu kunci atau individu-individu yang berdampak pada organisasi.

Menurut Wasesa (2006), kualitas obyektif adalah suatu titik yang dibingkai melalui interaksi penalaran individu ketika ia mendapatkan sejumlah data tentang suatu informasi. Kemudian, menurut Syam (2010), gambar adalah impresi mental atau gambar visual yang dihasilkan oleh kata, ungkapan atau kalimat, dan merupakan komponen esensial reguler dalam eksposisi atau karya ayat. Menurut Frank dalam Syam (2010), gambar merupakan konsekuensi informasi dan pemahaman atas suatu realitas yang ditangani dan disimpan dalam jiwa individu sehingga gambaran tersebut dapat diperkirakan melalui perspektif dan perasaan individu.

Fulfillment adalah kecenderungan kegembiraan atau kekecewaan individu yang muncul setelah sketsa kontras dengan pameran (atau efek samping) dari suatu item dan asumsinya (Kotler, 2007). Lupiyoadi (2011) berpendapat bahwa pemenuhan pembelanja pada barang 
iklan dan administrasi memiliki beberapa perbedaan, ada hal yang perlu diketahui dalam membantu menampilkan, karena administrasi mempunyai atribut utama.

Pengaturan perspektif dan standar perilaku pribadi pembeli terhadap pembelian dan penggunaan suatu barang atau administrasi merupakan konsekuensi dari pengalaman masa lalu mereka. Kualitas mentalitas yang signifikan yang bergantung pada pengalaman langsung adalah bahwa mentalitas biasanya dipegang dengan keyakinan yang lebih menonjol dan lebih mantap. Mengingat hal ini, pembeli memiliki keyakinan yang lebih beralasan tentang perspektif terhadap barang mereka ketika bergantung pada penggunaan barang daripada ketika bergantung pada data yang didapat.

\section{METODOLOGI}

Konfigurasi eksplorasi ini adalah rencana pemeriksaan yang mencerahkan. Penduduknya adalah wisatawan pantai di Provinsi Lampung berdasarkan informasi tahun 2019, tepatnya 17.183 jiwa. Kepastian penduduk harus difokuskan pada atribut dan peruntukan penduduk untuk mendapatkan populasi perwakilan atau benar-benar gambaran populasi dengan contoh 100 orang. Pengujian kuantitatif untuk menguji teori kerjasama (dampak antar faktor) menggunakan pendekatan Analisis Regresi Linier yang dalam perhitungannya memanfaatkan bantuan program aplikasi PC SPSS 18.00 for Windows. Berbagai Analisis Regresi Linear dengan perasaan

$\mathrm{Y}=\mathrm{a}+\mathrm{bX} 1+\mathrm{bX} 2+\mathrm{et}$

Data:

$\mathrm{Y}=$ Pemenuhan tamu variabel

$\mathrm{a}=$ Konstan

$\mathrm{b}=$ Koefisien relaps parsial

$\mathrm{X} 1=$ Keuntungan koneksi variabel

$\mathrm{X} 2=$ Kualitas obyektif variabel

et $=$ Kesalahan variabel (istilah kesalahan)

\section{DISKUSI}

Berdasarkan hasil pemeriksaan dan penanganan informasi, diperoleh berbagai informasi investigasi langsung kambuh sebagai berikut:

Tabel 4.14

Analisis Regresi Berganda

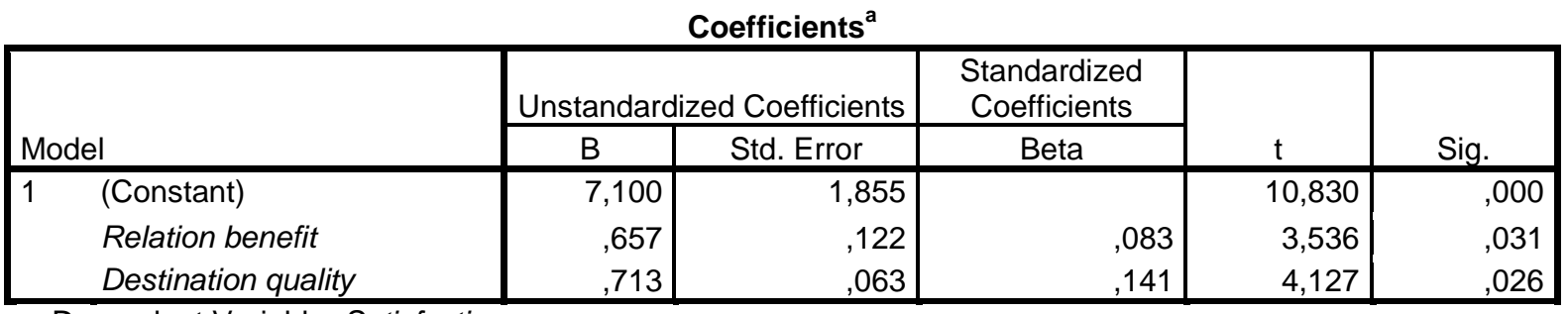

a. Dependent Variable: Satisfaction

Data disiapkan pada tahun 2021

Melihat tabel di atas, maka perlu diingat kondisi: $\mathrm{Y}=7.100+0.657 \mathrm{X} 1+0.713 \mathrm{X} 2+\mathrm{e}$. Efek samping dari kondisi tersebut menunjukkan bahwa keunggulan koneksi dan kualitas objektif memiliki dampak positif dan searah pada pemenuhan 
1) Setiap kali ada kenaikan estimasi variabel keunggulan koneksi, pemenuhannya akan bertambah.

2) Setiap kali terjadi perluasan estimasi variabel kualitas obyektif, pemenuhannya akan meningkat.

3) Berdasarkan data di atas, dapat disimpulkan bahwa koefisien relaps kualitas obyektif lebih menonjol daripada keuntungan koneksi sesuai dengan kecenderungan umum para tamu ke Pulau Pahawang untuk industri perjalanan. Tanda positif (+) menunjukkan bahwa jika keuntungan koneksi dan kualitas objektif meningkat, pemenuhan juga meningkat.

Uji t digunakan untuk menunjukkan apakah faktor bebas secara terpisah mempengaruhi variabel reliabel. Pengukuran uji dengan tingkat kepentingan $(\alpha)=0,05$ diselesaikan sebagai berikut: Jika thitung> ttabel, maka H0 dihilangkan dan Ha diakui. Dalam hal thitung <ttabel, maka H0 diakui dan Ha diberhentikan. Berdasarkan hasil pemeriksaan dan penanganan informasi diperoleh:

\section{Tabel 4.15}

Uji t

Coefficients $^{\mathrm{a}}$

\begin{tabular}{|c|c|c|c|c|c|}
\hline \multirow[b]{2}{*}{ Model } & \multicolumn{2}{|c|}{ Unstandardized Coefficients } & \multirow{2}{*}{$\begin{array}{c}\text { Standardized } \\
\text { Coefficients } \\
\text { Beta }\end{array}$} & \multirow[b]{2}{*}{$\mathrm{t}$} & \multirow[b]{2}{*}{ Sig. } \\
\hline & $\mathrm{B}$ & Std. Error & & & \\
\hline $1 \quad$ (Constant) & 7,100 & 1,855 & & 10,830 & , 000 \\
\hline Relation benefit & 657 & ,122 & ,083 & 3,536 & ,031 \\
\hline Destination quality & ,713 & ,063 & 141 & 4,127 & ,026 \\
\hline
\end{tabular}

a. Dependent Variable: Satisfaction

Data disiapkan pada tahun 2021

Diketahui bahwa hasil uji-t untuk variabel keunggulan koneksi adalah 3,536 (t hitung = 3,536 $>$ ttabel $=2,045)$ dan sig $=0,000<0,05$ yang berarti terdapat pengaruh manfaat koneksi atas pemenuhan tamu ke Pulau Pahawang industri perjalanan. Konsekuensi uji-t untuk variabel kualitas obyektif adalah 4,127 (thitung $=4,127>$ ttabel $=2,045$ ) dan $\operatorname{sig}=0,026$ $<0,05$ yang berarti terdapat pengaruh kualitas obyektif terhadap pemenuhan tamu terhadap kunjungan Pulau Pahawang.

Uji F sinkron digunakan untuk menunjukkan apakah semua faktor bebas yang diingat untuk model berdampak pada variabel reliabel. Uji F diselesaikan dengan melihat Fhitung dan Ftabel. Ftabel dapat dilihat melalui tabel-tabel yang dapat diukur pada arti 0,05 df =k-1 atau $2-1=1$ dan df $2=$ nk atau 100-3 = 102 ( $\mathrm{k}$ adalah jumlah faktor bebas), bilangan yang diperoleh adalah 2.100:

\section{Tabel 4.16}

Uji F

ANOVA $^{\mathrm{D}}$

\begin{tabular}{|ll|r|r|r|r|r|}
\hline Model & & Sum of Squares & df & Mean Square & F & Sig. \\
\hline 1 & Regression & 272,621 & 2 & 90,874 & 22,650 &, $000^{\mathrm{a}}$ \\
& Residual & 353,063 & 97 & 4,012 & & \\
& Total & 625,685 & 99 & & & \\
\hline
\end{tabular}

a. Predictors: (Constant), Relation benefit, Destination quality

b. Dependent Variable: Satisfaction

Data disiapkan pada tahun 2021

Berdasarkan hasil pengujian sinkron dari tabel di atas diperoleh Fhitung $=22.650>$ Ftabel $=$ 2.100, yang berarti terdapat pengaruh keunggulan koneksi, kualitas obyektif, dan kompensasi 
terhadap pemenuhan tamu terhadap kunjungan ke Pulau Pahawang. Koefisien jaminan bermaksud untuk mengukur sejauh mana kapasitas model dalam memperjelas keragaman variabel yang membutuhkan. Koefisien jaminan adalah $0<\mathrm{R} 2<1$. Koefisien jaminan yang mendekati satu menyiratkan bahwa faktor otonom memberikan hampir semua data yang diharapkan untuk mengantisipasi variabel yang membutuhkan. Penggunaan $\mathrm{R}$ square adalah satu sisi terhadap kuantitas faktor bebas yang diingat untuk model tersebut. Setiap faktor bebas ekstra ke dalam model, R square harus diperluas apakah variabel otonom memiliki pengaruh yang besar atau tidak. Berbeda dengan $\mathrm{R}$ square, nilai $\mathrm{R}$ square yang diubah dapat naik atau turun jika ada faktor bebas ekstra ke dalam model

\section{Tabel 4.17}

Hasil Uji Koefisien Determinan (Adjust $\boldsymbol{R}^{2}$ ) Model Summary

\begin{tabular}{|l|r|r|r|c|}
\hline Model & $\mathrm{R}$ & $\mathrm{R}$ Square & \multicolumn{1}{c|}{$\begin{array}{c}\text { Adjusted R } \\
\text { Square }\end{array}$} & $\begin{array}{c}\text { Std. Error of the } \\
\text { Estimate }\end{array}$ \\
\hline 1 &, $660^{\mathrm{a}}$ &, 436 &, 416 & 2,00302 \\
\hline
\end{tabular}

a. Predictors: (Constant), Relation benefit, Destination quality,

Data disiapkan pada tahun 2021

Hasil pengujian tabel nilai estimasi R sebesar 0.660, artinya hubungan antara faktor otonom (keunggulan koneksi dan kualitas obyektif) dengan variabel yang membutuhkan (pemenuhan) adalah 66\%. Bunuh koefisien jaminan R square sebesar 0,436 x 100\%. Artinya, setiap variabel otonom $(\mathrm{X})$ yang menggabungkan keunggulan koneksi dan kualitas obyektif memiliki komitmen bersama sebesar 43,6\% terhadap variabel terhubung (Y) Kepuasan, sedangkan sisanya diperjelas oleh elemen-elemen berbeda yang tidak dianalisis dalam penelitian ini.

Berdasarkan hasil uji-t untuk variabel keunggulan koneksi sebesar 3,536 (thitung $=3,536>$ ttabel $=2,045)$ dan sig $=0,000<0,05$ yang berarti terdapat pengaruh manfaat koneksi terhadap pemenuhan tamu ke Pahawang. Kunjungan pulau. Pertunjukan sosial menunjukkan bahwa hubungan antara organisasi dan klien yang dipilih dimasukkan ke dalam hubungan jangka panjang yang biasanya membantu. Evan dan Laskin (2006): menyatakan bahwa menampilkan hubungan adalah cara untuk menarik, menjaga dan meningkatkan hubungan dengan individu kunci. Berdasarkan pemahaman di atas, peningkatan hubungan dapat dikatakan memiliki arti penting, sebagai siklus menarik, menjaga dan meningkatkan asosiasi dengan individu kunci atau individu yang berpengaruh pada organisasi.

Hasil penelitian ini menjunjung tinggi penelitian sebelumnya, lebih spesifiknya Litle dan Marandi (2010) yang menyatakan bahwa periklanan relasional adalah sistem elektif terhadap pendekatan campuran yang menampilkan adat sebagai metode untuk memperoleh keuntungan ekonomis dan pendekatan paling ideal untuk menahan klien. dalam jangka panjang. Bicket (2009) menyatakan bahwa mempromosikan hubungan adalah menampilkan basis informasi yang menggarisbawahi sudut pandang periklanan yang terkait dengan upaya kumpulan data. Burhn (2010) yang menyatakan bahwa social advertising sebagai semua kegiatan menyelidiki, mengatur, mengakui dan mengendalikan perkiraan yang memulai, menyelesaikan, meningkatkan dan memulai asosiasi bisnis dengan mitra organisasi, khususnya klien, untuk membuat nilai bersama.

Berdasarkan hasil uji-t untuk variabel kualitas obyektif sebesar 4,127 (thitung $=4,127>$ ttabel $=2,045)$ dan sig $=0,026<0,05$ yang berarti terdapat pengaruh kualitas obyektif terhadap pemenuhan tamu di Pulau Pahawang. industri perjalanan. Seperti yang ditunjukkan oleh 
Kotler dan Keller (2012), "Kualitas adalah mutlak dari sorotan dan atribut dari suatu item atau administrasi yang sesuai dengan kapasitasnya untuk memenuhi kebutuhan yang diungkapkan atau disimpulkan". Administrasi atau administrasi yang diberikan kepada pembeli oleh organisasi jelas harus sangat baik. Gronroos, dikutip oleh Sutisna dan Suhartanto (2008: 507), mencirikan hubungan keuntungan sebagai berikut: "Kualitas bantuan absolut dilihat oleh klien sebagai korelasi antara bantuan normal, yang diharapkan individu yang bersangkutan, dan melihat administrasi yang menurut klien dia benar-benar telah diterima ". Pengertian kualitas administrasi menurut Wyckof dalam Tjiptono (2006) adalah: "Derajat kebesaran dan penguasaan yang normal atas derajat kebesaran ini untuk memenuhi keinginan klien".

Parasuraman, Zeithaml, Berry dalam Tjiptono (2006) mengatakan bahwa terdapat dua faktor utama yang mempengaruhi kualitas administrasi, yaitu antisipasi bantuan dan pengawasan administrasi. Jika bantuan didapat atau dilihat (lihat administrasi) sebagaimana bantuan biasa, maka kualitas bantuan yang terlihat jelas terlihat. Bagus. Dalam hal pendampingan melebihi asumsi klien, kualitas administrasi dipandang sebagai kualitas yang ideal. Sebaliknya, jika yang didapat lebih rendah dari yang diharapkan, sifat bantuan tersebut dianggap buruk. Sejalan dengan itu, jika sifat bantuan dapat diterima bergantung pada kapasitas koperasi spesialis untuk memenuhi klien mereka secara andal.

\section{KESIMPULAN}

Mengingat efek samping eksplorasi dan percakapan, hal itu dapat menjadi alasan yang sangat tepat

a. Ada dampak positif dan besar dari keunggulan koneksi terhadap pemenuhan tamu di industri perjalanan Pulau Pahawang.

b. Ada dampak positif dan kritis kualitas obyektif pada pemenuhan tamu di Pulau Pahawang industri perjalanan.

c. Ada keunggulan hubungan dampak positif dan kritis serta kualitas obyektif terhadap pemenuhan tamu dalam kunjungan ke Pulau Pahawang.

\section{INDEKS BUKU}

Adnegara. 2019. Pandangan Kepuasan Wsata: Stud d Desa Wsata Blmbngsar Bal. Jurnal Global.

Alma, Buchar. 2015. Mempromoskan Manajemen dan Pemasaran Jasa. CV. Alfabeta. Bandung

Arkunto, Suharsm. 2016. Metodolog Ujan. Dstrbutor PT. Rneka Cpta. Jakarta.

Bagozz, Rchard P. 2008. Panduan Perseptual dan Pemossan Produk. Jurnal Seluruh Duna.

BPS Provns Lampung. 2019. Jens Wsata d Provns Lampung. Bandar Lampung.

Dnas Kebudayaan dan Parwsata Provns Lampung. 2018. Profl ndustr Wsata Provns Lampung. Bandar Lampung.

Had, Purnama. 2012. Prnsp Perklanan. Jld V. Erlangga. Jakarta

Hasan, Al. 2008. Perklanan. Yogyakarta. Meda Pressndo.

Hasbuan, Malayu P. 2015. Manajemen Sumber Daya Manusa. Penjamn: PT. Lteras Bum. Jakarta.

Indonesa Unta Mankams d Khatulstwa. 2015. Pesona Parwsata ndonesa. Jakarta. Kotler Phlp dan Armstrong, Garry. 2008. Standar Pemasaran. Jld . Erlangga. Jakarta 2012. Prnsp Perklanan. Jld V. Erlangga. Jakarta 2016. Standar Pemasaran. Jld V. Erlangga. Jakarta

Lupyoad, Rambat, 2011, Manajemen Pemasaran Jasa Eds 2, Jakarta. empat salemba, 
Notoatmodjo, Soekdjo. 2016. de dan Penerapan Metodolog Peneltan. Jakarta: PT. Rneka Cpta.

Osman. 2013. Dampak loyaltas konsumen pada membantu kualtas dan kepercayaan Hubungan d pedesaan Malaysa ndustr perjalanan. Jurnal Global.

Ostasevcute. 2008. Aspek Hpotess Postonng Produk d Pasar. Jurnal Seluruh Duna.

Pantanesa. 2019. Profl Wsata Pessr d ndonesa. Jakarta.

Perera. 2016. Dampak kualtas admnstras terhadap pemenuhan dan kesetaan klen Koperas Dadrah d Dl, Tmor-Leste. Buku haran ujan.

. 2017. Dampak Bagan Tujuan ndustr Perjalanan, Kualtas Admnstras terhadap Kesetaan Objektf Melalu Pemenuhan Wsatawan d Taman Margasatwa Ragunan. Buku haran ujan.

Pryatno, Burhan. 2016. Metode Peneltan Sosal dan Bsns. Eds pertama. Yogyakarta: lmu Graha

Rachma, Sr. 2010. Ujan Product Postonng pada Clothng Arena Experence Bandung. Jurnal Ujan UNB Bandung.

Resno. 2017. Keunggulan Relasonal dan Kualtas Layanan d Wsata. Jurnal Seluruh Duna.

Robbns, Stephen P. 2015. Perlaku Berwenang. Penerbt Salemba Empat. Jakarta.

Soegoto, Eddy Soeryanto. 2009. Bsns. Eds pertama. Jakarta: PT. Elek. Meda Komputndo.

Sugyono. 2015. Metode Peneltan Regulas. Dstrbuter Alfabeta Bandung.

2016. Metode Peneltan Subyektf. Kuanttatf dan R\&D. Dstrbuter Alfabeta Bandung.

Swastha, Basu dan rawan. 2016. Manajemen Penawaran. Jld . BPFE. Yogyakarta

Tjptono, Fandy. 2012. Pemasaran Utama. Yogyakarta.

Utam, Chrstna Whdya. 2010. Manajemen Rtel. Jakarta: Salemba Empat.

Wahyud, Agus. 2016. Metodolog Peneltan Keuangan. FEU. Jakarta

Wasana, Jaka. 2008. Analss Laporan Anggaran. Jakarta: PT RajaGrafndo Persada.

www.indonesia.travel. 2020.

www.pesonalampung.com. 2020. 